\title{
Static Archive: UIN-ANA Service Development Model
}

\author{
Marhamah Saleh \\ Lecturer of Islamic Education FITK, \\ Syarif Hidayatullah State Islamic \\ University Jakarta, Indonesia \\ marhamah@uinjkt.ac.id
}

\author{
Lolytasari \\ Head of the Library of FITK UIN Syarif, \\ Syarif Hidayatullah State Islamic \\ University Jakarta, Indonesia \\ lolytasari@uinjkt.ac.id
}

\author{
Hasbana Amrullah \\ Head of the Library of UIN Syarif, \\ Syarif Hidayatullah State Islamic \\ University Jakarta, Indonesia \\ amrullah@uinjkt.ac.id
}

\begin{abstract}
This study aimed to describe the static archive acquisition model applied by Gadjah Mada University (UGM) Yogyakarta, as the first role model and embryo of the establishment of an archive maintenance and rescue unit called as the University Archive. In addition, it is to identify the availability of the Library Center of UIN Syarif Hidayatullah Jakarta as the center of scientific knowledge management and historical information resources within the university, in developing the acquisition of the collective memory collection regarding UIN Jakarta called as UIN-ANA Service. This research applies a qualitative method using field research and case study approach. Data obtained from observation, documentation, and interview with archival manager and leader of University Archive UGM Yogyakarta. The result of the research shows that UGM's acquisition of archives is focused on collective memory by receiving and/or collecting static archives from creator units (work units) within UGM, academic, individual, or other institutions that retain and/or have static archives related to UGM. The availability of UIN Syarif Hidayatullah Library Center Jakarta in developing a static memory collection called UIN-ANA Service (now known as UIN Syahid- ana), is by serving open access to society by not only providing thesis, dissertation, reference book but also collection documents in print or electronic form such as books, magazines, newsletters, scientific papers, photographs, videos, letters, decisions, manuscripts, articles written by UIN Syarif Hidayatullah Jakarta lecturer and others articles about UIN Syarif Hidayatullah Jakarta, and all related to the history of UIN Syarif Hidayatullah Jakarta. The Result of the research recommends stakes holder of UIN Syarif Hidayatullah to adopt, develop, and modify UGM archives acquisition for the Library Center of UIN Syarif Hidayatullah Jakarta, by establishing special units in managing static archives, and recruiting professional archivist in archival area to build archive center in UIN Jakarta.
\end{abstract}

Keywords - The acquisition of static archives; University archive; UIN-ANA Services; service development model; static archives

\section{INTRODUCTION}

The acquisition of the archive is the implementation of an activity program on the static archive handover, as mandated by Government Regulation No. 28/2012 concerning
Implementation of Law No. 43 of 2009 concerning Archives. Following the mandate of this Law, various government agencies and universities are seeking to submit inactive archives that have retention at least 10 years carried out from archival units within the work unit to archival institutions.

The transfer of responsibility for the management of this archive aims to be preserved and placed on a static archive storage unit. The storage point of static archives of State Institutions, State-Owned Enterprises, Political Parties and Societal Organizations and national figures are located in the Archival Depo of ANRI (National Archives of the Republic of Indonesia). While at the college level where static archive storage is known as the University Archive [1, p. 1] or in the archive regulation in Indonesia referred to as the University Archives Institution.

One of the state universities that have implemented the acquisition of historical- valued archive is Gadjah Mada University (UGM). Yogyakarta. UGM is the first embryo of the establishment of an archive and rescue unit called as the University Archive. The UGM's rules use in applying static archive acquisition are the Rector of Gajah Mada University Regulation No. 192/P/SK/HT/2011 concerning Guidelines for Acquisition of Archive in the Work Scope of Gadjah MadaUniversity.

UGM has acquired some archives including (1) archives containing the establishment of institutions/organizations and working procedures, (2) archives containing cooperation related to universities resulting in juridical impact, (3) archives containing policies, (4) efforts of university, (5) policy formulation, (6) planning and implementation program, (7) archives of figures within UGM, (8) archives related to cases within UGM and (9) archives related to intellectual achievement within UGM.

The description of the process of static archive acquisition conducted by the University Archive of UGM shows that in acquiring static archives it needs legal binding guidance and rules. It is understandable that objects managed and organized are archives that have administrative, legal and informational values. The facts are in line with a statement of McKemmish regarding the importance of standards and guidelines on archive creation and maintenance, acquisition 
policies, assessment guide lines and terms of transfer and access policies. [2, pp. 16-17].

On the other hand, the results of a research conducted by Lilik Istiqoriyah et al in 2013, entitled Management of Historical-Valued Archives at UIN Syarif Hidayatullah Jakarta in the Era of Information Disclosure, indicates that UIN Syarif Hidayatullah Jakarta has not owned static archive management guidelines including historical archives. UINS's archive scattered in different unit, both in the faculty and institutions within UIN Jakarta. In addition, the historical archive storage that has been done by each unit within UIN Jakarta, is limited to the archive storage in the policy form of saving in a collection of decisions format, whether the Presidential Decree, Ministerial Decree or Rector Decree, [3, p. 66]. In response to this phenomenon, the Library Center of UIN Syarif Hidayatullah Jakarta as the center of scientific knowledge management and historical information resources within UIN Syarif Hidayatullah begins to think about collective memory collection regarding UIN Jakarta, which is called as UIN-ANA Services.

Suprayitno in his research entitled Implementation of static archive acquisition at Archives Center of Gadjah Mada University Yogyakarta (A Case Study) in 2013, stated that UGM in the implementation of static archive acquisition was guided by Archive Retention Schedule (ARS) and in submitting archives to UGM Archive the Minutes were made.[4, p. 132]. ARS is a list containing at least a retention period, type of archive, and information containing recommendations on the establishment of a file type destroyed, revalued, or made permanent, which is used as a guide for depreciation and rescue of records. (http://www.anri.go.id/detail/863-160-Konsultasi-

Penyusunan-JRA-Pusat). This research confirms the importance of ARS as one of the pillars of orderly management of archives, so as to improve the quality of archive implementation and ensure the security of information, the retention of static archives as a source of information, evidence of performance accountability and collective memory of thenation.

Furthermore, Siti Maryam in her research entitled Evaluation of Library Collection of UIN Syarif Hidayatullah Jakarta Based on Citation Analysis of Lecturer Research in 2015 concluded that the Library Center of UIN Syarif Hidayatullah Jakarta as one of the vital components of Three Higher Education Commitments had variations of collection, including: Printed books, journals, magazines, online database, e-books, multimedia collections and academic work articles included thesis and dissertation.[5, p. 93]. The study has indeed succeeded in depicting the literature treasury owned by the Library Center of UIN Jakarta, but has not shown significant progress on the acquisition of archives, for example, by establishing a special unit. At this point this research becomes strategic and important premise toundertake.

Ultimately, this study aims to describe the static archive acquisition model applied by Gadjah Mada University (UGM) Yogyakarta, as the first role model and embryo of the establishment of an archive maintenance and rescue unit called as the University Archive. The next goal is to identify the availability of the Library Center of UIN Syarif Hidayatullah Jakarta in developing the archive acquisition and collective memory collection on UIN Jakarta called UINANA Services.

By obtaining a comprehensive description and identifying existing problems, it is expected to contribute positively to archive managers and Library in making intellectual acquisition program of academic work at UIN Syarif Hidayatullah Jakarta.

\section{METHOD}

The primary source in this research is UGM Rector's Regulation Number 192/P/SK/HT/2011 concerning Guidelines for Acquisition of Archive within UGM, and manuscript source, document archives and published sources, produced by people directly involved in the event, activity, or early-pioneering process of establishing the University Archives.

Primary source is further reinforced by information from secondary source, which presents interpretation, analysis, explanation, reviews from informants and UGM archivists

and Library of UIN Syarif Hidayatullah Jakarta.

The method used is qualitative method with field study approach and a case study, in which the researcher carefully investigates a program, event, activity, process or group of individuals.[6, p.20]. The research setting was conducted at Archives Room of Gadjah Mada Yogyakarta located at 3rd Floor L Building, UGM Library Complex, Special Region of Yogyakarta. In addition, a research was also conducted to the Library Center of UIN Syarif Hidayatullah Jakarta and some Faculties Library within UIN Syarif HidayatullahJakarta.

Data obtained from observation, documentation, and interview with archival managers and head of UGM Yogyakarta University Archives, and Head of Library Center of UIN Syarif Hidayatullah Jakarta who was directly involved in the management of static archives.

\section{RESULT AND DISCUSSION}

The research findings are focused on two issues: The first, is related to the profile of Gadjah Mada University (UGM) Yogyakarta and University archives, UGM archive organization, archive program, archive acquisition model, static archive acquisition characteristics, and static archive acquisition procedure within UGM. The second focused on concerning the Library Center Organizational Structure of UIN Syarif Hidayatullah Jakarta, and the development of UIN-ANA services through the acquisition of static archives. UGM was located at Bulaksumur Yogyakarta, and also as the oldest university, which was established on December 19, 1949. At the beginning it had 6 faculties, and now has 18 Faculties, 1 Post-Graduate School both S2 and S3. Based on UGM Rector Regulation Number 1/P/SK/HT/2015, UGM Archive organization structure was at the University Executive Element, in which there were parallel 
implementing units included Library, PPTIK, KP4, LPPT, University Archive, PPP and Hospital. In the implementation of duties, the Head of UGM Archives was assisted by a Secretary and divided into 2 areas namely: (1) Service Division and (2) Data base Division.

UGM archives have programs and tasks such as: (1) formulating the policy strategy of UGM Archives; (2) formulating the guidance on the implementation of the archive; (3) coordinating the management and preservation of the archive; (4) coordinating services in the archives; (5) coordinating the development of the archival system; (6) coordinating and evaluating the implementation of archives within UGM, (7) conducting guidance on human resources of UGM Archives; and (8) conducting guidance on the organization of archives within UGM. (Rector of Gadjah Mada University Regulation No. 1/P/SK/HT/2015 concerning the Status, Function and Tasks of Organization within Gadjah Mada University, 2015:3-4).

The archive acquisition model of UGM is focused on the collective memory located at Universitas Gadjah Mada. Collective memory is the archive created by the archive creator as a recording of information created and accepted by UGM in various forms recorded in paper, audio visual, computer / electronic media and special media, whether in single or group state in the framework of the implementation of Three Higher Education Commitments and University Administration. Archive Creator Units at UGM are all working units at UGM, include: (1) Office of the University Management, (2) Institute for Research and Community Service, (3) Directorate, (4) Study Center, (5) Library, (6) Information Technology and Communication Service Center, (7) University Archive, Integrated Research and Testing Laboratory, (8) Education Garden, Agriculture Research and Development, (10) Education Development Center, (11) Internal Audit Unit, (12) Campus Security Unit, (13) Alumni Administration and Business Development Office, (14) Office of Cooperation Administration, (15) Career Development Center, (16) Vocational School Administration Office, (17) Faculty and (18) Post-Graduate School. Most static archive acquisitions that have been performed using structural acquisition receiving archives from archive creation units and rarely using unstructured acquisition method collecting available archives. This means that the Archives of the University of Gadjah Mada receives the transfer of archives from the created unit but has not picked up those archives from the creatorunit.

There are 9 kinds of characteristics that must be acquired to UGM Archives, among others include:

1. Archives containing the establishment of institutions/organizations and working procedures (how institutions are established, developed, amended or regulated);

2. Archives containing cooperation/contracts, universityrelated agreements that have juridical impact, general and continuous effect;

3. Archives containing policies/instructions either directly or indirectly;

4. University efforts related to ideology, political, economic, social and cultural products;

5. Archives containing provisions relating to personnel, policy formulation;

6. Archives containing provisions relating to personnel, policy formulation;

7. Archives of national figures, Echelon I and II Officials, Civil Servants equivalent to Rank IV/d and IV/e within UGM;

8. Archives of outstanding events /cases;

9. Archives of intellectual achievements include: research results, dissertations, inaugural speeches, Dies Natalis (Anniversary) speeches, and others.

The process of archive acquisition at UGM is generally shown by temporal handover (transfer), donation and archive borrowing. Each unit makes its own acquisition based on the guideline, only then submitted to the University Archive. The submission of the archive is evidenced by the Deed of Donation which is an acknowledgment letter to the donors who have submitted their archive to the University Archive. Through the process of donation, the archive will increase the treasury of UGM Archives by collecting archives through archive donation requests to individuals, work units, communities, private institutions, other groups and associations. Transfer of archives is the activity of collecting archives through the transfer of archives from work units within the University to UGM Archive on a sporadic basis or not scheduled as in Archive Retention Schedule (ARS), meaning that when the archive has entered the period of static retention it must be transferred to the UGM Archive. Transfer of archives must be accompanied by proof letter of transfer. The archive borrowing is to collect the archives through the receipt of archival materials lent from any party to the UGM Archives for the purpose of temporary or special-purpose and limited borrowing, as evidenced by the Letter of Borrowing Agreement.

The next focus of the findings pertains the Structure of Library Center Organization of UIN Syarif Hidayatullah Jakarta, and the development of UIN-ANA services through the acquisition of static archives. Speaking about UIN Syarif Hidayatullah Jakarta, certainly not apart from the historical development of ADIA, PTAIN, IAIN and UIN as a collective memory of institutional treasury. In 2013 there was a change in new ORTAKER (Organization and Work Procedures) within UIN Syarif Hidayatullah Jakarta, which impacted to a change in the organizational structure, including the Library. The Head of Library Center is assisted by 3 sub-divisions, including (1) Head of Library Administration Sub-Division, (2) Coordinator of Technical Services and Cooperation Development and (3) Library Information Services and Information Literation Coordinator.

UIN-ANA, organize different type of materials, it organizes more on scholarly materials rather than archives. It's a collection of local content includes thesis, dissertation and research report which is a work deposit of UIN alumni 
and a small part comes from articles of McGill University alumni (particularly thesis and dissertation). The existence of UIN-ANA collection is expected to support webometric improvement. This is in accordance with the Rector Circular of UIN Syarif Hidayatullah Jakarta that all academicians are obligated to participate in increasing the citation of UIN Syarif Hidayatullah Jakarta. Among them is to require every student to quote the scientific work of lecturers and each lecturer is encouraged to quote his / her own scientific work (not copy and paste) and to quote fellow lectures who are experts in theirfield.

In addition, the Library of UIN Syarif Hidayatullah Jakarta also has a collection of printed materials and nonprinted materials (e-resources). The printed collections that are provided at the Library of UIN Syarif Hidayatullah Jakarta, among other include: (1) Islamic and general collections, (2) reference collection, (3) UIN-ANA collections, (4) collections of periodical (serial) edition, (5) corners \& TAF collections, and (6) game collections. While the non-printed collection is divided into various formats, including online e-journal, e-book and e-database, Most of these e-resources are subscribed by the Library Center and can be accessed online subject to conditions set by the Library Center. The focus of this research is the collection of UIN-ana.

The development of UIN-ANA services through the acquisition of the static archive is any document collection in any form published by UIN human resources or other people concerning UIN Jakarta. If this understanding is linked to Archival Science it will be mentioned as the acquisition of a static archive. Efforts intensification and extensification of library treasures at UIN Jakarta has been pursued through various methods. Among them, the Faculty of Shari'a and Law has undertaken the Movement of Library Materials Wakaf (Endowments) pioneered by the Dean of the Faculty of Shari'a. Even this movement is reinforced by the issuance of Dean Decree of Faculty of Shari'a and Law with regard to Wakaf Movement of Library Materials. The purpose and objective of this movement is to encourage lecturers to grant their own work articles to be stored and served in theLibrary.

If UGM has owned the University Archive, then the issue that should be discussed is how to realize the same one at UIN Jakarta, given the urgency of the archive institution and the implementation of the mandate on the law that must be fulfilled by all StateUniversities.

\section{CONCLUSION}

The conclusion of this research is that the acquisition of archive implemented by UGM is focused on the collective memory by receiving (for structured acquisition) and/or collecting (for unstructured acquisition) static archives from archival creating units (work units) within UGM, academic, individual, or other institutions that retain and/or have static archives related to UGM. UGM has held its own structure in managing the archives supported by archivists as professional records managers. This institution also has a standard guidance in applying the static archive acquisition as stated in
UGM Rector Regulation Number 192/P/SK/HT/2011 regarding Guidance of Implementing Archive Acquisition within UGM. The availability of UIN Syarif Hidayatullah Library Center Jakarta in developing a static memory collection called UIN- ANA Service (now known as UIN Syahid-ana), is by serving open access to society by not only providing thesis, dissertation, reference book but also collection documents in print or electronic form such as books, magazines, newsletters, scientific papers, photographs, videos, letters, decisions, manuscripts, articles written by UIN Syarif Hidayatullah Jakarta lecturer and others articles. about UIN Syarif Hidayatullah Jakarta, and all related to the history of UIN Syarif HidayatullahJakarta.

The implication of this research; it recommends stakes holder of UIN Syarif Hidayatullah to make the model of archives acquisition at UGM can be adopted, developed, and modified by the Library Center of UIN Syarif Hidayatullah Jakarta, by establishing special units in managing static archives, and recruiting professional archivist in archival area to build archive center in UIN Jakarta.

\section{REFERENCES}

[1] M. Effendhie. "Memahami Dasar Pemikiran Dan Penyelenggaraan Arsip Universitas," $1999 . \quad$ [Online]. Available:http://arsip.ugm.ac.id/web/download/2104112251ARSIPUNIVERSITAS.pdf.

[2] S. McKemmich. "Introducing Archives and Archival Programs. Dalam Judith Ellis (Ed.)," 2nd ed. Port Melbourne: DW Thrope, 1993.

[3] L. Istiqoriyah and Lolytasari. "Pengelolaan Arsip Bernilai Historis UIN Syarif Hidayatullah Jakarta Di Era Keterbukaan Informasi," 2013. [Online]. Available: http://journal.uinjkt.ac.id/index.php/al maktabah/article/view/1588/1331

[4] Suprayitno. "Implementasi Akusisi Arsip Statis Di Arsip Universitas Gadjah Mada Yogyakarta (Studi Kasus)," 2013. [Online]. Available: http://digilib.uin-

suka.ac.id/12072/1/BAB\%20I,\%20V,\%20DAFTAR\%20PUSTAKA.p df.

[5] S. Maryam. "Evaluasi Koleksi Perpustakaan UIN Syarif Hidayatullah Jakarta Berdasar Analisis Sitasi," Penelitian Dosen, 2015.

[6] J. W. Creswell. Research Design Pendekatan Kualitatif, Kuantitatif Dan Mixed. 3rd ed. Yogyakarta: Pustaka Pelajar, P. 201 